\title{
Making the Ghetto at Luník IX in Slovakia: People, Landfill and the Myth of the Urban Green Space*
}

\author{
RICHARD FILČÁK and ONDREJ FICERI** \\ Slovak Academy of Sciences, Bratislava
}

\begin{abstract}
The prevailing public perception of Luník IX, a Roma district in the Slovak city of Košice, is that it represents the story of an originally urban green space, one of the best for healthy living given its fresh air and proximity to the forest, that was destroyed by 'naïve' decision-makers and 'irresponsible' Roma. This article, based on a combination of qualitative sociological and historical research, questions this narrative and deems it a myth. The district's proximity to a landfill and the consequent environmental effects of this played a decisive role in its ghettoisation, yet these factors have never been systematically analysed and discussed. Although Luník IX was not officially and originally designed as a ghetto, it became one as a result of structural, social, and environmental factors. Utilising the conceptual and theoretical framework of environmental justice, the article focuses on the spatial distribution of the adverse environmental effects in relation to social and ethnic factors. The case of Luník IX, with its roots in the period of a centrally planned economy, provides a unique opportunity to make a comparative study of the social processes from a historical perspective. It allows us to analyse the mechanism of decision-making in an avowedly non-capitalist society, where in reality we see many similarities in how income inequality between richer and poorer neighbourhoods, together with ethnic/racial factors, has shaped the city.
\end{abstract}

Keywords: environmental justice, Roma ethnic minority, Luník IX, urban ghetto

Sociologický časopis/Czech Sociological Review, 2021, Vol. 57, No. 3: 293-313

https://doi.org/10.13060/csr.2020.048

\footnotetext{
* Acknowledgements: This work was supported by the projects APPV - MARGIWORK (An Analysis of Barriers in Access to Employment for Marginalised Groups of the Population: Selected Regions of Slovakia in Socio-economic, Geographic and Socio-anthropological Perspective) and VEGA 2/0084/19 (Luník IX: The Past, Present and Future of the Roma District). We thank Mária Hajduová, Michal Tunega, and Peter Anna from the Municipal Archive of Košice (Archív mesta Košíc), as well as Richard Pavlovič, Erik Dulovič and Katarína Durčanová from the State Archive in Košice (Štátny archív v Košiciach) for providing us with the archive material needed to prepare this paper.

** Direct all correspondence to: Richard Filčák, Center of Social and Psychological Sciences, Slovak Academy of Sciences, Šancová 56, 81105 Bratislava, Slovak Republic; e-mail: filcak. richard@gmail.com; Ondrej Ficeri, Center of Social and Psychological Sciences, Slovak Academy of Sciences, Karpatská 1337/5, 04001 Košice, Slovak Republic; e-mail: ondrej. ficeri@saske.sk.
}

(C) Sociologický ústav AV ČR, v. v. i., 2021

(C) Authors, 2021 


\section{Introduction}

Luník IX in Košice has over the years become a symbol of the 'impossibility' of Roma integration in Slovakia. For the outside world it is an example of failed inclusion policies, yet for the people who live there it is a severe social stigma. It strongly influences public discussion surrounding public housing for marginalised communities, but it has also very tangible impacts on its inhabitants and it effectively excludes them from the labour market. ${ }^{1}$

Since 1990, Luník IX has been a self-governed district within the municipality of Košice with its own mayor, deputy assembly, kindergarten, and elementary school. In 2013, approximately 6200 people lived there in segregation from the rest of the city's population. More than $50 \%$ of the local housing stock was demolished in 2008-2017, but 3100 people are still living there in blocks of flats [Mesto Košice 2017: 12]. Almost all of them belong to the Roma ethnic minority. ${ }^{2}$

In this article, we challenge the public discourse that describes the Luník IX district as originally a 'beautiful forest area' that has been destroyed by 'naïve' decision-makers and 'irresponsible' Roma. The article analyses the central role played by the municipal landfill in the ghettoisation of this place, whereby the myth of the urban green space has functioned as a pretence to justify and legitimise the failed practices of non-Roma decision-makers and to concurrently reinforce antigypsyism sentiment among the majority populace.

We focus on three interconnected research questions: (1) What is the historical/recorded story of the landfill and what role have the landfill construction and environmental factors played in turning the place into a ghetto? (2) How can we analyse the process from an environmental justice perspective, i.e. how do economic, social, and ethnic factors lead to the inequitable distribution of environmental risks and benefits? (3) How much are the historical facts reflected in the present explanatory narratives?

Our methodological approach is based on a case study design combined with an analysis of historical records. In addressing our key research questions, we combine qualitative research methodology based on semi-structured interviews, participatory and non-participatory observations, and text analysis with a desk study of historical records in the Košice municipal archives. We built a 'purposive sample', where we began with specific perspectives identified through text analysis (i.e. newspapers, media, municipal documents, and statements) and then identified research participants who represent the full range of perspectives.

\footnotetext{
${ }^{1}$ Being from Luník IX effectively prevents people from getting jobs. In several interviews, we obtained similar descriptions of cases where just revealing a permanent address here leads to cancelled job interviews. There are estimates that $95 \%$ of people of productive age and living in Luník IX are unemployed [Mesto Košice 2013: 29].

2 A minor portion of inhabitants (around 250), who were evicted from their flats, built scattered shacks in the adjacent forest area called Mašlíčkovo.
} 
In the course of the qualitative survey in 2018-2019, we analysed the perspectives of city administrators, politicians, journalists, researchers, and NGOs. The research was not specifically focused on the ghetto's Roma inhabitants, but we did conduct a series of visits and interviews with the people, NGOs, and representatives of the district council at Luník IX. ${ }^{3}$ Documents from 1965 to 1989 preserved in the State Archive in Košice and the City Archive of Košice provided key data on decision-making processes in the period of state-socialist Czechoslovakia at the local level.

In the first part of the article we provide a theoretical and conceptual framework for the analyses of the social, economic, and environmental policy factors that shaped urban decision-making in the state-socialist period and in the post1989 neoliberal era. In the second part, we systematically follow step by step the timeline of Luník IX's origin in relation to the city's waste management practice and its consequent socio-spatial development. Here we confront the prevailing popular narrative with historical facts from our archive research.

The article concludes with a discussion of how Luník IX, although not officially and originally designed as a ghetto, became one, and what was the role of environmental factors in this process. Mass housing at Luník IX, with its roots in the period of a centrally planned economy and witnessing rapid adverse development in the transformation period, provides a unique opportunity for a comparative study of environmental justice from a historical perspective. It allows for an analysis of the mechanism of decision-making in a society that declares it is cut off from capitalism, while in reality we see in it many similarities to the market economy, and how income inequality among richer and poorer neighbourhoods, together with ethnic factors, has shaped the city of Košice.

\section{The space we live in: the conceptual framework of environmental justice}

Contrary to the general perception of socialist regimes as 'monolithic dictatorships', recent scholarship argues that many policies executed by state-socialist authorities were the outcome of negotiations between several actors positioned at different levels, from the level of the central government through to the local level, including, for example, common complaints from ordinary citizens [Pullmann 2011; Spurný 2012; Blaive 2018]. ${ }^{4}$ We can make a similar argument about the general perception of socialist regimes as 'command economies'. ${ }^{5}$ The system

\footnotetext{
${ }^{3}$ How the landfill is reflected in the perception of the people it affected would deserve further research using anthropological methodology.

${ }^{4}$ Moreover, it must be stressed that the situation varied in different Eastern Bloc countries and even in different decades.

5 The term 'command economy' is used to describe a system in which the government, rather than the free market, determines the quality, quantity, and price of goods.
} 
possesses various market elements. Drawing on the ideas of Karl Polanyi [1944], just as we see elements of control and planning in 'market economies', we may also see elements of a market in so-called centrally planned economies.

The principal difference between a market and a centrally planned economy can be seen in the type of capital possessed, deployed, and controlled by social actors. While in the former it is predominantly financial combined with social, in the latter it is primarily social combined with financial - in the form, for example, of various types of favours, bribes, or barter trades. The system described by Janos Kornai $[1980,1988]$ as one of frequent, intensive, and chronic shortages developed its own mechanisms of distribution and access to goods and services. An item in demand, such as an apartment, is there, but the buyer has to queue up for it, and the waiting list may be many years in length. When you get a chance or access to certain goods in shortage, in this case an apartment, you have to accept the quality and location, since your bargaining power is limited [Kornai 1988; Lipton and Sachs 1990]. However, as we analyse in our case study, the limits of individual and collective bargaining power may differ significantly and depend to a great extent on a person's class and/or ethnic affiliation. Luník IX, the biggest ghettoised urban space in Slovakia, illustrates the differences as they evolved during the transition from a centrally planned system to a market economy.

Luník IX, where the vast majority of inhabitants today belong to the Roma ethnic minority, falls into a category for which, by deploying the Wacquantian qualification criteria of stigma, spatial confinement, constraint, and institutional encasement, we can use the term 'urban ghetto' [Wacquant 2004, 2011]. As we will argue, it is no accident that the ghetto evolved in proximity to a municipal landfill. Deploying an environmental justice perspective helps us to understand how the presence of the environmental burden initiates, reinforces, and/or leads to such segregation. Mary Douglas [1966] puts exclusion in the broader context of the social order. In other words, impure bodies and impure things are pushed to the margins and isolated to protect the social order. Luic Wacquant sees this as an inherent feature in the formation of a ghetto, the purpose of which is 'to minimize intimate contact with its members so as to avert the threat of symbolic corrosion and contagion they are believed to carry' [Wacquant 2012: 7].

Environmental justice, rooted in the study of inequality and exclusion, encompasses the dimension of distributive and procedural justice. Building on David Schlosberg's [2002, 2007] approaches, we define it here as the equitable distribution of environmental risks and benefits reached through fair and meaningful participation in environmental decision-making. In other words, it is about not only who gets what, but also what procedures are involved. Although, as we will argue, race is of key importance in our case, as Razmig Keucheyan [2016] notes, the racial variable is not an isolated one and it is mixed in with other variables especially class. Or, as Laura Pulido [2010: 13] puts it: 'Race is liable to produce differentiation within a class position and, in turn, class is liable to produce differentiation within a given ethno-racial belonging.' 
There are many types of settlements in which the poor, migrants, or ethnic minorities seek places to settle, or where they end up through a combination of economic, social, and sometimes political pressures. Such places are usually an amalgam of overcrowding, poor or informal housing, tenure insecurity, unclear property rights, problematic residence permits, and inadequate access to safe water and sanitation. Another common feature is that these places tend to be located on the outskirts of big cities or on the peripheries of villages. As Mike Davis [2004: 1] observes: 'The urban poor ... are everywhere forced to settle on hazardous and otherwise unbuildable terrains - over steep hillslopes, riverbanks and floodplains. Likewise, they squat in the deadly shadows of refineries, chemical factories, toxic dumps, or in the margins of railroads and highways.'

The breakthrough study conducted by the United Church of Christ Commission for Racial Justice, a church-based civil rights organisation, came to the conclusion that ' $60 \%$ of African Americans live in communities with at least one abandoned toxic waste site' [CfRJ 1989: xiii]. Extending this research and additional surveys, in 1990 Robert Bullard published Dumping in Dixie: Race, Class, and Environmental Quality as the first textbook on environmental justice [Bullard 1990]. This was followed by extensive research in the United States to map and analyse the relationship between race, class, and the distribution of environmental benefits and harms [Bullard 1993; Schlosberg 1999; McGurty 2000; Pellow 2002; Rhodes 2003]. A study of the locations of Integrated Pollution Control Sites (i.e. registered most polluting enterprises) in the United Kingdom concluded that 'out of the 3.6 million estimated people living within $1 \mathrm{~km}$ of a site, there are 6 times more people from the most deprived decile compared to the least deprived' [Walker et al. 2003: 23].

These disparities were studied in the context of very different countries. Kathleen Millar [2018] in Jardim Gramacho, Rio de Janeiro's main garbage dump, and Adrian-Octavian Dohotaru [2013], in the case of Pata-Rat in Romania, illustrate how waste lies at the heart of relations of inequality. It is not only about exposure to environmental risks. People living at or next to the problematic sites are subject to exclusion and stigmatisation.

The ethnic prejudices and racisms that are usually found at the root of segregation play a key role in the location of certain settlements. Environmental factors may influence the location of segregated spaces and/or serve as the accelerators of ghettoisation processes. There is a growing number of studies of the Roma ethnic minority in Central and Eastern Europe that have identified direct or indirect environmental factors in the process [Ladanyi and Szelenyi 1998; Steger et al. 2007; Filčák 2012; Vincze and Rat 2013; Filčák and Steger 2014; Velicua and Kaikab 2015; Holifield et al. 2017; Picker 2017].

For a better understanding of Luník IX and its origin as an urban ghetto, we need to place the settlement in the context of the dichotomy between official national policies of social inclusion and the local urban context. The officially declared goals of the former (here we refer to the period prior to 1989) and present 
governance (post-1989 liberal democracy) in reality faced and face strong local interests.

The theory of the town as a growth machine or urban growth machine suggests that the objective of growth unites otherwise pluralistic interests in relation to a city. Set within the framework of the commodification of place theory, it explains the often contradictory interests behind decisions concerning a particular place and its social and economic value and environmental and social externalities. According to this approach, developed by Harvey Molotch [1976] in collaboration with John Logan [Logan and Molotch 1987], a city or human settlement is not driven by simple market logic, that is, as though vacant parcels of land that have commercial or social value are just waiting to be exploited by developers or citizens. In fact, and perhaps even more important, the parcels of land will increase in value if there is an interest in them. Cities and settlements must therefore be analysed from the perspective of their organisation, management structure, and lobbies, and from the point of view of decision-makers and developers.

When it comes to urban development, local elites are often in various firmer or looser associations with politicians, businesses, local media, and other stakeholders and form coalitions that claim proposed plans or activities will benefit everyone. The very principle of the 'growth engine' is, however, different. Urban development transforms the city and its value in the use of all, yet the exchange value of a few [Logan and Molotch 1987]. What a settlement looks like is not just determined by impersonal market or geographical constraints/factors, or in the case of centrally planned economies, simply by the decisions of the Communist Party. It is also the result of social processes and inequality of opportunities. Environmental aspects play an important and sometimes even decisive role in shaping the space.

Investors are restricted by the economic and social interests and power of owners and at the same time seek to locate controversial activities (e.g. landfill, heavy industry factories, or any operation with some negative impact on the environment) in places where they can expect the best price of land and the least resistance from the population.

While during the communist period the official party line was not questioned by the public, how the state's policies were implemented at the urban level in the end depended somewhat on the local context and public and private interests. Decisions on practical matters, such as urban planning and decisions about Roma settlements, were, to a great degree, influenced by the local decisionmakers, reflecting shared prejudices against the Roma minority, addressing the economic interests of various stakeholders in obtaining a better quality of life for their families or simply by not going against the prevailing public opinion and take popular decisions.

The urban strategies that reflect and reproduce antigypsyism sentiments and, simultaneously, function as a means of establishing the political legitimacy of ruling elites at the local level were analysed in the case of the segregated Roma 
district Chánov in the northern region of the Czech Republic by Matěj Spurný [2016], and Matoušek and Sýkora [2011] conducted similar research on Vsetín in the Czech Republic. Similar patterns were already described in the 1990s in Hungary [Ladanyi and Szelenyi 1998] and are also the subject of intensive research in Romania [Dohotaru 2013; Vincze and Rat 2013]. What is similar here to these and other cases is their rooting in the former regime of a centrally planned economy and their continuation and sometimes expansion in the newly established liberal market democracies.

Unlike other major Roma ghettos in Central and Southeast Europe, and despite extensive social media coverage dedicated to Luník IX in Slovakia and abroad since 1989, the genesis of the ghettoisation process of Luník IX has so far attracted only limited attention from domestic and foreign scholars. A pioneering study on the history of the district was recently produced by Slovak historian Anna Jurová [2015], who interprets the creation of the district as the outcome of the deliberate antigypsyist policies of the local authorities. Similarly, Luník IX serves as a case study of Aidan McGarry's work Romaphopia [2017], analysing racial behavioural patterns on the part of the non-Roma Slovak populace, which he audaciously describes as 'a modern day apartheid' [ibid.: 136]. None of the authors, however, analysed the ghetto's evolution in relation to the localisation of the landfill in the area.

\section{Urban myth, people, and the landfill}

The popular image of Luník IX is one of a Communist Party plan for a superior green housing area that went wrong. The two prevailing explanatory frameworks can be described as a 'naïve experiment that failed' and 'good intentions but the wrong implementation'.

The first framework was the one typically adopted by experts in Košice's city administration, the city's social welfare experts, and it is basically identical to the prevailing perception of the public and media coverage. The following quotation from an interview with an employee at Košice City Hall is typical: 'They got the best apartments in the city, under the forest, green, nice... A stupid policy of the city in the past... [they] moved the Roma there ... it was impossible [for non-Roma] to live there with those people. They have destroyed the area completely...' One motive often presented was that it was an experiment that was doomed to fail from the very beginning because the 'inability of the Roma to adapt to normal life'.

In the words of another respondent: 'The communists gave these apartments to the Roma for free, but ... These people don't appreciate what they got - they destroy everything. ${ }^{17}$ Respondents typically referred to the former (before

\footnotetext{
${ }_{6}^{6}$ Personal interview with a representative of Košice administrative authority, June 2018.

7 Personal interview with an elected official in Košice City Hall, June 2018.
} 
1989) state and municipal authorities and the Communist Party as naïve decision-makers, driven by ideology instead of building on practical knowledge of the Roma ethnic minority. The central themes of the narrative are representations of Luník IX as a green space, designed as one of the best places for healthy living, with fresh air and proximity to the forest.

The second, minor explanatory framework builds on the narrative of 'good intentions but the wrong implementation'. The central theme of this framework is a story about an attempt to create an ethnically mixed neighbourhood, but the party and municipal officials failed. In the words of one respondent: 'They mixed different clans, families; they did not use any form of social work, community work. The [Communist] Party made the decision, but in the former regime they simply did not have the knowledge, the tools, to manage the situation. ${ }^{8}$ The idea of a mixed neighbourhood was in this perspective and in principle a good one, but it should not have involved a mass-scale eviction from the city, and should not have been applied to an unprepared community and with a lack of fieldwork conducted among members of the minority and the majority - the process was basically lacking in all knowhow and good practices, which were not available prior to the political changes. This explanatory framework was the one typically espoused by NGO representatives, the Roma and Roma activists, and respondents from the academic sector.

We argue that both narratives are false and that Luník IX is neither the outcome of good intentions nor a failed experiment. Its history cannot be analysed without understanding the central role played by the local landfill. The district is spatially segregated from the city by a stream and by Myslavská Street, a fourlane road with heavy traffic. ${ }^{9}$ When we examine the map (Figure 1), we see that the mass socialist-era blocks of flats are close to the municipal landfill. The first apartments are only a hundred metres from this source of population and the whole housing estate, including the elementary school, is no more than 500 metres from it. The only connecting road to the housing estate also has heavy traffic that is due to waste transport.

Therefore, in the second part of the in-depth interviews we focused on the landfill. We purposely did not introduce the topic and almost none of the nonRoma mentioned the landfill as an issue on its own. The Roma inhabitants of the area were aware of the landfill, but if was not considered a decisive factor in shaping the space. To some extent, this may be explained by the fact that the landfill

\footnotetext{
${ }^{8}$ Personal interview with an employee of an NGO, June 2018.

9 The district is served by one bus line with a 'special regime', which means that unlike other local public transport routes serving the city proper, which operate on an honour system, in the case of this line all passengers have to show a valid ticket to the driver on embarking. Korzár 2006. 'Autobusová linka č. 11 už na Lunik IX premávat' nebude' (Bus route no. 11 will no longer serve Luník IX). Košice: Korzár: Sme. Retrieved 8 March 2019 (https://kosice.korzar.sme.sk/c/4475500/autobusova-linka-c-11-uz-na-lunik-ix-premavat-nebude.html\#ixzz5i4IlwIca).
} 
Figure 1. Location of the landfill in Košice - Myslava and the position of Luník IX

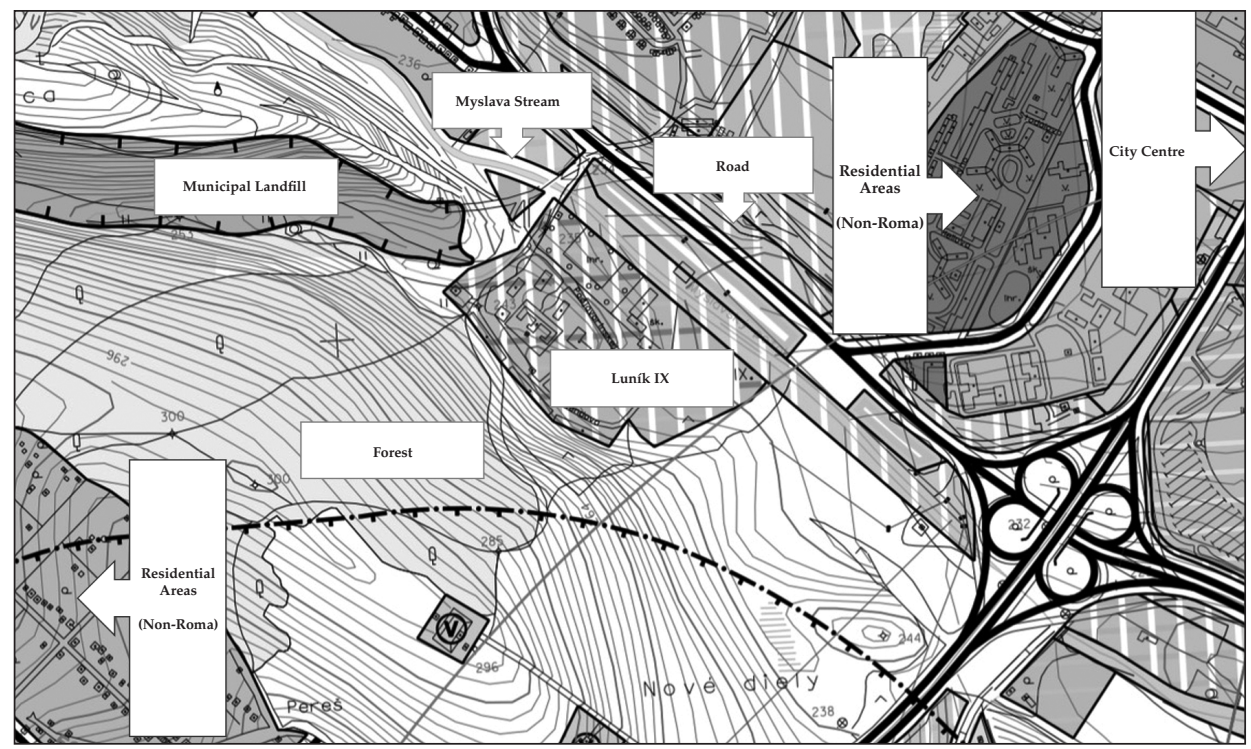

Source: Department of the Chief Architect of the City of Košice. The Town Planning Scheme of the Economic-Residential Agglomeration of Košice, 2018.

was closed in 1997. Alternatively, we may also consider Daniel Sosna [2016], who sees landfills as places pushed to the margins of human perception.

Contrary to the present narrative analysed in the qualitative survey, historical records indicate that the landfill was in fact a very important part of the formation of Luník IX. Housing and waste management would be of major importance for any city that developed as rapidly as post-war Košice. Rapid industrialisation meant there was a need to house more than 100000 workers, including families and construction staff. The construction of Nové Mesto (New City), a major satellite housing project for 60000 inhabitants, commenced in 1960. By 1963, the authorities had designated two other localities for satellite housing in the form of blocks of flats, which are now the Košice city districts Dargovských hrdinov (30 000 inhabitants) and Košického vládneho programu (28 000 inhabitants). An unoccupied field site on the western periphery of the city, later named Luník IX, did not figure in any of the plans for the construction of mass housing.

The modernist urbanisation of the outer city contrasted with the rather semi-rural built-up area of the inner city. The deprived pre-war housing stock of the city centre and its former suburbs appealed as a pull factor for the immigration of rural Roma inhabitants, who by 1965 - together with Roma who had long lived in a centrally located but slum-style quarter in the city called 'Tábor' - al- 
ready accounted for 9000 inhabitants or 10\% of Košice's population. Such a high concentration of Roma in the city's urban space put the municipal officials in a tight corner for two reasons: (1) constant complaints from the majority population regarding the 'asocial' behaviour of some Roma, such as filthiness, noisiness, bad hygiene, thievery, and truancy; this gave rise to an unwillingness to 'live next door to a Roma', ${ }^{10}$ and (2) the need to comply with the 1965 Government Decree on the elimination of all separate Roma settlements, including Roma rural camps and urban neighbourhoods, and the subsequent dispersion of Roma families among the majority populace [Jurová 1993: 77].

As a consequence of the contradictory interests of the local majority population on the one side and governmental policies on the other, Košice municipal officials declared the directive policies from the central government to be impracticable in the local environment and instead attempted to push forward a plan for creating a brand-new Roma district on the very periphery of the city, where the majority of the most 'asocial' families, approximately 720 from the total of 996 Roma families, would then be accommodated. ${ }^{11}$ This proposal was partly backed by representatives of the East-Slovakia County, who recommended that the government's dispersion policy not be applied to the 'most backward families'. ${ }^{12}$

However, the crucial problem with the proposed 'solution' transpired to be that of finding a suitable location for a segregated district within the city's borders. During the 1960s and 1970s, the population of Košice grew rapidly, from a population of 80000 (1961) to 200000 (1980), making it the fifth-largest city in Czechoslovakia. The city's planners and engineers had to address cumulative environmental and logistical issues connected with the city's unprecedented growth, such as providing a sufficient supply of heat and water and solving waste management by replacing an older municipal landfill (Červený Rak) with a more capacious one (1969). ${ }^{13}$ Concurrently, a 1960 government decree anticipated

\footnotetext{
${ }^{10}$ Koordinačná komisia rady MsNV pre riešenie otázok spoluobčanov cigánskeho pôvodu v Košiciach, plán práce na II. polrok 1965 (Coordination Council of the Municipal National Committee for Solving the Problems of Co-citizens of Gypsy Origin in Košice, working plan II/1965), Box 70/4, fond Mestský národný výbor Košice 1959-1970 (Municipal National Committee in Košice, hereinafter MNKK), Archív mesta Košíc (Municipal Archive Košice, hereinafter MAK), Košice, Slovakia.

${ }^{11}$ Kontrolná správa o plnení komplexného plánu riešenia otázok občanov cigánskeho pôvodu v Košiciach na rok 1966 (An audit report on delivering outcomes of the complex plan for solving the problems of citizens of Gypsy origin in Košice), 1966, 3440/66, Box 70/4, fond MNKK, MAK, Košice, Slovakia.

12 Súčasný stav a hlavné smery v zameraní tvorby životného prostredia vo Východoslovenskom kraji (The current state and main tendencies in environmental management in the Eastern Slovakia County), March 1968, 55, 8/1968, Box 158, fond ESNK, SAK, Košice, Slovakia.

${ }^{13}$ Rozvoj Technických služieb mesta Košíc do roku 1980 (Development of the technical services of the city of Košice to 1980), 4 December 1969, 935-15, Box 105, fond MNKK, Technické služby mesta Košíc, MAK, Košice, Slovakia.
} 
Figure 2. Timeline of the decision-making process leading to the construction of Luník IX contrasted with the development of the waste management system in Košice

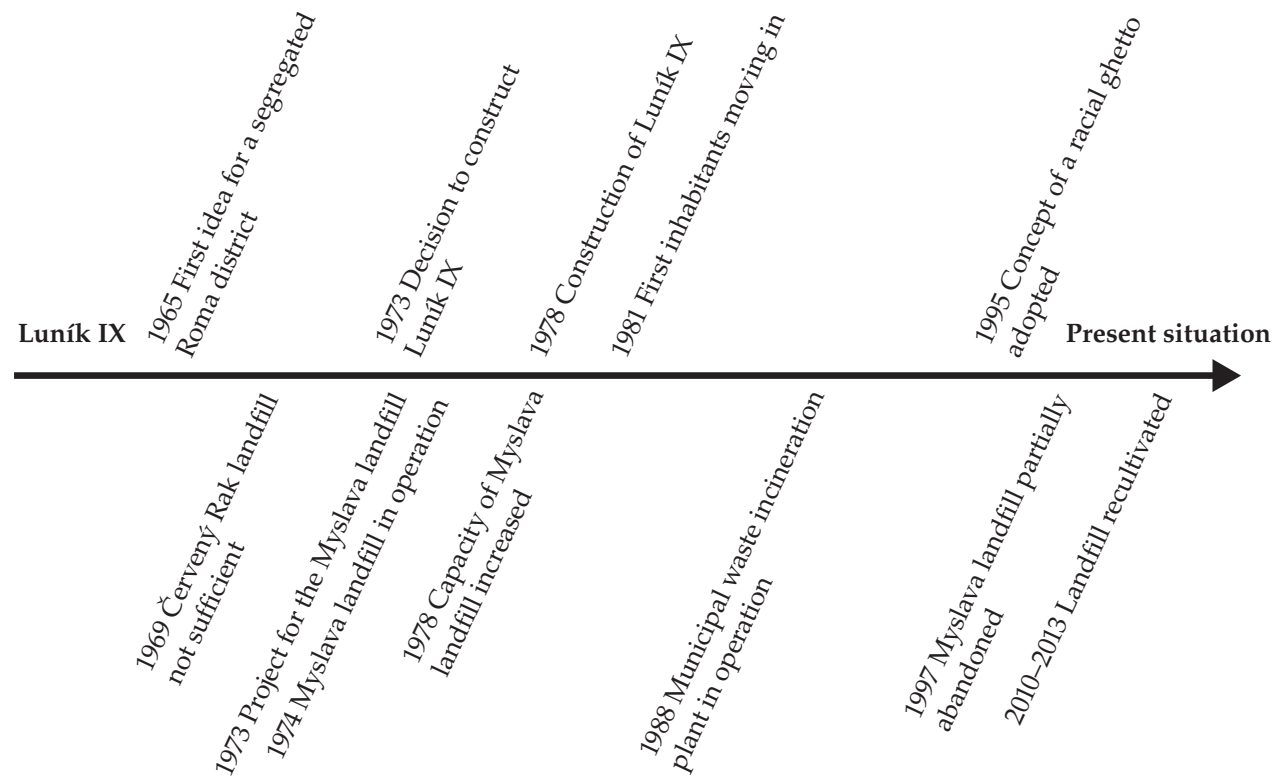

the creation of extensive municipal forest parks 'in order to offset the negative impacts of the industrial city on the quality of life of its inhabitants' ${ }^{14}$ Considering that one-third of Košice's administrative area was already under a building ban because of excessive exhalates from the iron works, and another third because of the high noise levels from Košice's international airport, it was clear that some of the city's planned projects (the landfill, the Roma district, the forest parks) would spatially collide with each other. Figure 2 illustrates the timeline.

Under these circumstances, it was the local Roma who got the short end of the stick, as the Roma were not represented as an ethnic group by any Roma citizens in any municipal bodies. Because of the lack of suitable land, in 1973 Košice's municipal authority decided to place the proposed segregated Roma district in the very proximity of the newly created municipal landfill in Myslava. The main argument for locating the landfill in Myslava was its spatial 'invisibility', as it was supposed to be embedded in a chasm surrounded by a forest. The second argu-

\footnotetext{
${ }^{14}$ Návrh na prehlásenie d’alších hospodárskych lesov v okolí Košíc na účelové lesy II (A draft for the reclassification of further commercial forests for special purpose forests II), 30 October 1972, 355/76/72, Box 172, fond MNKK, Organizačný odbor 1975, MAK, Košice, Slovakia.
} 
ment concerned the prevailingly northern wind, which was supposed to prevent the odour from spreading in the direction of the city proper..$^{15}$ The archival documents reveal that the city's decision-makers were not willing to make any concessions on moving the landfill beyond the city borders, for two pragmatic reasons: (1) negotiations with reluctant country/county officials that take years would significantly postpone the urgently needed solution to waste management, and (2) placing the landfill too far from the city proper would result in higher transportation costs. No consideration whatsoever was given to how close the landfill would be to proposed dwellings for people - the future district Luník IX - or to the fact that on the site of the projected access road to the landfill there was already a small Roma camp, which, naturally, immediately had to be demolished. ${ }^{16}$

The main justification for placing the two urban projects next to each other was that the Myslava landfill was only expected to exist until the central municipal waste incineration plant was built, i.e. until 1978, when the construction of Luník IX was supposed to commence. After that the landfill was supposed to be recultivated; thus, inhabitants of Luník IX would not have been environmentally disadvantaged. However, the centrally planned calculations fell short of expectations. Not only was the construction of the waste incineration plant postponed until 1986, but because of an excessive increase in waste disposal, the lifespan of the landfill was already about to expire in 1979/1980. ${ }^{17}$ Thus, the Košice municipal officials were placed in a tight spot again, as they had to make a decision about whether to relocate the landfill beyond the city's borders and to make a fair distribution of environmental burdens, or to prolong the lifespan of the Myslava landfill until the completion of the waste incineration plant, which meant that the inhabitants of Luník IX would inevitably be impacted by the negative environmental effects of living so close to the landfill. Contrary to the objections of urban planners and engineers and waste management experts, who called for the landfill to be closed, Košice municipal officials gave priority to increasing the landfill's size by an additional $90000 \mathrm{~m}^{2}$ to a total area of $12.5 \mathrm{ha}$, at the expense of the nearby forest and increasing the overall waste storage height to 15 metres. ${ }^{18}$

\footnotetext{
${ }^{15}$ Projektová úloha na areál novej skládky mestského odpadu Košíc (Project for the site of a new municipal landfill), January 1973, 236/72/d, Box 104, fond MNKK, Technické služby mesta Košíc, MAK, Košice, Slovakia.

${ }_{16}$ Projektová úloha na cestné mosty na obslužnej ceste $\mathrm{k}$ areálu novej skládky mestského odpadu Košíc (Project for a road bridge on a service road to the area of the new central municipal landfill for Košice), January 1973, 236/72/d, Box 104, fond MNKK, Technické služby mesta Košíc, MAK, Košice, Slovakia.

17 Záznam z jednania vo veci riešenia skládky mestského odpadu (A report from proceedings on the issue of resolving the municipal landfill), 12 July 1977, 2352/77, Box 105, fond MNKK, Technické služby mesta Košíc, MAK, Košice, Slovakia.

${ }_{18}$ Informatívna správa o potrebe zabezpečenia dalších skladovacích priestorov mestského odpadu pre mesto Košice (An informative report on the need to securing further municipal waste storing areas for the city of Košice), 24 October 1977, Box 105, fond MNKK, Technické služby mesta Košíc, MAK, Košice, Slovakia.
} 
At the same time, the municipal officials regarded the removal of 'asocial' Roma families from the inner city as being the most challenging environmental issue of the decade, one that had to then hindered reconstruction of the historical heritage in the city centre. The site of a concentrated Roma slum-style quarter within the city called 'Tábor', which in the process of the city's rapid urbanisation had come to be centrally located, was also to be bulldozed and turned into a park. The original intention to remove as many Roma from the inner city as possible was in the municipal agenda actually legitimated by two objectives: (1) social policy - to provide standard-class housing for the Roma like for any other citizen of Czechoslovakia, and (2) disciplinary policy - to re-educate the Roma in a specialised, concentrated, and segregated district:

'[Asocial Roma families] adjust to the living standards of socialist man with severe difficulty. They neglect hygiene, do not properly raise their children, are addicted to alcohol, tend to be parasites, dodge work obligations, and engage in anti-social activities. It is necessary to remove them from the valuable historical quarter and relocate them to other parts of the city, where it will be possible to influence in the concentration of them by means of re-education. ${ }^{19}$

However, the original plan of the municipal officials could not be implemented as planned because the central government in Bratislava rejected the idea of creating an experimental district to be inhabited by Roma only, and insisted on the dispersion policy implemented in 1965. Consequently, a part of the municipal housing stock was offered to 'socialist elites', policemen and soldiers; they, however, refused the offer and preferred to live in other housing estates..$^{20}$ Thus, the claim featured in the popular narrative about Luník IX as being constructed as an originally elitist neighbourhood is yet another myth surrounding this housing estate.

After the city planning experts had calculated that adhering to the government dispersion policy would not solve the 'Roma issue' at the local level even by 1990, the municipal officials allocated all 204 of the municipal flats in Luník IX from the 502 flats constructed in total in Luník IX to Roma families. The remaining 298 cooperative flats were allocated to non-Roma families. A total of 1197 Roma inhabitants moved into the 204 municipal flats in Luník IX; they accounted for only $14 \%$ of all the Roma in Košice. The remainder continued to live dispersedly in the city proper. ${ }^{21}$

\footnotetext{
19 Kontrolná správa o realizácii opatrení na úseku riešenia otázok cigánskych obyvatelov $\mathrm{v}$ okrese Košice-mesto (An audit report on implementing measures in the area of solving issues connected to Gypsy inhabitants in the municipal district of Košice), 4 April 1982, 6279/82, Box 305, fond MNKK, Predsedove spisy, MAK, Košice, Slovakia.

${ }^{20}$ Výkazy o pridelovaní bytov (Housing stock assignment accounts), 29 January 1982, C149/81, Box 8, fond ESCNC - Zvláštne oddelenie 1971 - 1990, SAK, Košice, Slovakia.

${ }^{21}$ Súčasný stav plnenia úloh súvisiacich so spoločenskou a kultúrnou integráciou cigánskych obyvatelov v okrese Košice-mesto a úlohy i opatrenia na ich realizáciu pre roky 1981 - 1985 (Current state of the fulfilment of tasks connected to the societal and cultural
} 
Although Roma occupied only a minority of the flats in Luník IX, because of their preference for living as extended and joint families and their higher fertility rates, they accounted for more than $50 \%$ of local inhabitants. Moreover, the forced displacement of the relocated Roma, which in many ways disrupted their natural socialisation, traditionally organised on the principle of related clannish kin, generated conflicts not only in terms of 'majority versus minority' but also among Roma clans differently positioned in the clan hierarchy [Jurová 2015: 46]. By 1982, following mass protests from both non-Roma families and acculturated (the expression used in documents) Roma families, it was agreed that the 15 most 'asocial' families would be moved out of the district. However, if an acculturated Roma family already living in the district requested a replacement flat in the city proper, the authorities rejected such requests. ${ }^{22}$

A 1982 report on the living standards in Luník IX acknowledged the failure to fairly distribute environmental risks: 'The location of the housing estate [Luník IX] is very unfortunate because located in its immediate proximity is the municipal landfill (dump), from which they [Roma designated as 'asocial'] are picking mixed garbage and taking it home. The hygiene here is extremely poor, hence the conditions are ripe for the spread of an epidemic. ${ }^{23}$

The district's built-up area extended as far as just 500 metres to the south of the landfill and there was a smell of waste all over the district. The municipal officials 'calmed' the inhabitants of Luník IX by assuring them that the only solution to the problem would be to build a waste incineration plant. ${ }^{24}$ However, the incineration plant did not open until 1988, a decade behind schedule. Despite constantly repeated promises on the part of city officials, the landfill was not abandoned and continued to operate until 1997.25

The issue of the gradual departure of non-Roma from the district in the 1980s and the early 1990s remains a sensitive one in local urban memory; there are therefore no official data. The records from the Municipal Housing Company

integration of Gypsy inhabitants in the municipal district of Košice, relevant arrangements and measures to be realised in 1981 - 1985), 27 March 1981, 57, fond MNKK, Rada MsNV 125, MAK, Košice, Slovakia.

22 Záznam z mimoriadnej porady predsedov ObNV Košice I-V (A report from an emergency briefing of district deputies Košice I-V), 10 May 1982, Box 105, fond MNKK, Predsedove spisy, MAK, Košice, Slovakia.

${ }^{23}$ Stanovisko k riešeniu otázok cigánskych obyvatelov v okrese Košice-mesto (A report on the solution to issues connected to Gypsy inhabitants in the municipal district of Košice), 6 May 1982, Box 305, fond MNKK, Predsedove spisy, MAK, Košice, Slovakia.

24 1981. 'Zápach zamoril ovzdušie, plač nad rozpočtovou dokumentáciou, netreba sa obávat', jediné východisko - výstavba spal'ovne' (There's a stink in the air and tears over the budget, but no need to worry, the only solution is to build the incineration plant). Večer, 9 September 1981, vol. 13, no. 177, p. 2.

25 The landfill was a significant environmental burden on its neighbourhood until its recultivation in 2010-2013, which was co-financed by EU Cohesion Funds [Uhrínová 2013]. 
were not made accessible to us because of the legislation in effect on personal data protection. According to the respondents, some non-Roma families managed to sell their flats before 1995 to other non-Roma families with lower income. By 1995, there were still 250 non-Roma families living in cooperative flats in the district. ${ }^{26}$ However, in 1995, after the cooperative flats were transferred by the state to municipal ownership, the municipal officials adopted a policy that essentially copied the original intention from the 1960s to create a segregated Roma district - a ghetto. According to this policy, all nonpayers of rent and bills in the city proper - mostly Roma families - were moved to Luník IX in exchange for non-Roma families, who received the chance to move out and into vacated flats in the city proper (around 150 families) or to a newly built housing estate called Ťahanovce (100 families). ${ }^{27}$ The gentrification of the inner city that occurred during the neoliberal economic transformation pushed the remaining Roma families out of the city and into to the periphery as well [Mesto Košice 2013: 10].

\section{Luník IX and the environmental justice perspective}

In the public discourse, burdened by communist ideology, the district was initially depicted as ideal housing 'in a picturesque environment offering the possibility to pick forest fruits in the summer and to go sledding in the winter' ${ }^{28}$ However, the reality was very different. The proximity to the Myslava landfill resulted in some of the Roma inhabitants 'picking' rubbish, contaminating the housing area with waste and annoying other cohabitants with the smell and noise. The place was exposed to the heavy traffic of trucks transporting waste. In 1995, the local press described Luník IX as 'Košice's dump', while explicitly and exclusively referring to the unpleasant situation of the 'whites' still left at the dump. ${ }^{29}$

The urban space at Luník IX had ghettoisation tendencies from the very beginning and the development after 1995 was the final stage of this process. The position of the Roma in Košice has historically been similar to the position of the Roma in many other places in Central and Eastern Europe, Czechoslovakia, and, later, Slovakia. A stigmatised minority, with weak social and economic capital,

\footnotetext{
${ }^{26}$ Personal interviews with inhabitants and former inhabitants of the Luník IX district, September 2019.

${ }_{27}$ Koncepcia bývania pre neplatičov, bezdomovcov a neprispôsobivých občanov (Housing plan for non-payers of tax, the homeless, and nonconforming citizens). Decree of $\mathrm{Mu}-$ nicipal Assembly no. 55, 5 April 1995. Mesto Košice (1995). https://www.kosice.sk/clanok. php?file=gov_koncepcia_sb.htm.

28 1981. 'Tisíce schodov radost' neskalili. Medzi prvými obyvatel'mi Luníka IX' (A thousand steps did not cloud their joy: among the first inhabitants of Luník IX). Večer, 12 August 1981, vol. 13, no. 157, p. 3.

29 1995. 'Bieli zostanú zatial' na smetisku' (Whites will remain at the dump for the time being), Večer, 23 November 1995, vol. 27, no. 225, p. 1.
} 
they were more the object than the subject of public policies. While representatives of the former state-socialist regime verbally declared the goal of full social integration of the Roma minority, in reality they faced resistance from local municipal officials and ordinary inhabitants. The paradox is that the liberal democracy after 1989 faced the very same challenge of the disconnect between official policies and local practice.

Contrary to the widespread myth about Luník IX being a 'forest suburb' destroyed by Roma, historical records further reveal that contemporary decisionmakers before 1989 had no intention of investing in the environmental improvement of the district whatsoever. Unlike any of the other mass housing projects in the city (Nad Jazerom, Dargovských Hrdinov, KVP, Ťahanovce), where nearby forest areas were turned into forest parks with recreational facilities as soon as the estate was completed, this was not even planned in the case of Luník IX. ${ }^{30}$ The serious environmental problems present at this location were at the roots of the ghettoisation process and once the space was created, they contributed to the 'beyond the pale' syndrome, wherein environmental injustice leads to further environmental degradation, not only by putting the people 'outside', but also by violating sound environmental practices, as the 'normal' or 'usual' rules of operation do not apply [Filčák 2012].

The landfill and its environmental impacts were strong factors with respect to why the Roma from Košice were gradually concentrated in this space. Evidence from historical records suggests that the explanatory narrative in the prevailing public perception and media presentation of Luník IX as the story of an urban green space destroyed by 'naïve' decision-makers and 'irresponsible' Roma is basically false. The process of ghettoisation here followed a logic centred on the landfill.

An analysis of the process reveals that the decision-makers were aware of the environmental burden connected with the locality from the very beginning. The idea of creating a mixed neighbourhood 'pushed' by the central government soon became illusory. The non-Roma inhabitants 'placed' there through the allocation of flats were from the very beginning not happy with the neighbourhood. Luník IX became a stigmatised place because of the presence of the landfill and the increasingly high concentration of Roma in the population. The district's spatial segregation from the city and its gradual ghettoisation impacted the market value of their flats.

Non-Roma were, in the terms of Janos Kornai's economy of shortages [1980, 1988], pulled there by the availability of apartments, but were trying from the very

\footnotetext{
30 Súborné stanovisko a pokyny pre ukončenie územného projektu obytnej zóny Ťahanovce $\mathrm{v}$ Košiciach (A comprehensive standpoint and instructions for completion of the planning project for the Ťahanovce urban housing zone), 18 January 1983, Box 308, f. Národný výbor mesta Košice (National Committee of the city of Košice), Organizačný odbor, Primátorove spisy, MAK, Košice, Slovakia.
} 
beginning to exchange the flats and move out. That, however, was not easy. As one of the respondents described it: 'Exchanging flats was a popular practice among the people in the 1980s, but when it came to negotiations it soon became popular to say I will exchange my flat for any other one except one in Luník IX.'31 The Roma were forced to live there, as they were forcibly evicted from the dwellings they had occupied in the central parts of the city. ${ }^{32}$ Unlike the non-Roma, for Roma there was never any attempt by the city to help them resettle elsewhere.

Although we do not possess relevant socioeconomic data on the last remaining non-Roma families who left the district in 1995, we may assume that these were people who were unable to exchange their flat before that or did not have suitable accommodation elsewhere. Eventually, the municipality invested in the construction of new communal flats in the district Ťahanovce, where the remaining Luník IX non-Roma families moved. The others received municipal flats in other parts of the city. As one former city hall employee recalled: 'The flats at Luník IX were practically impossible to exchange or sell and these people were looking at us like saviours when we moved them out. ${ }^{33}$ There was very little construction of new flats in this period..$^{34}$ The preferential treatment given to nonRoma in Luník IX can be seen as as result of a combination of public (non-Roma) pressure $^{35}$ and the social capital of those involved, and in this connection we can cite what Alena Ledeneva [1998] calls 'economies of favour' or the ubiquitous use of personal relations to obtain scarce goods and services. Košice ultimately accomplished segregation. Two years after those non-Roma families left, in 1997, the city closed the landfill and commenced reclamation work. This helped to improve environmental conditions, but structural barriers to the Roma's social integration remain.

\section{Conclusion}

The process that turned Luník IX into a ghetto includes a cross-section of factors relating to housing policy, the decision-making process, and, lastly, geography. Why this happened there and not somewhere else is no accident. The nature

\footnotetext{
31 Personal interview, June 2018.

32 These evictions were propelled by ethnic discrimination and especially after 1989 by commercial interests.

${ }^{33}$ Personal interview, July 2018.

34 While in the 1980s average the number of new apartments constructed amounted to 20690 units per year, in 1995 the figure was just 6230 [Slovak Statistical Bureau, 2019]. The construction of social and rental housing almost ceased entirely in the 1990s [Gajdoš and Moravanská 2016].

35 1995. 'Dost' bolo slubov: mesto kontra smutne preslávený Luník IX' (Enough with the promises: city hall contra the sadly famous Luník IX), Večer, 16 August 1995, vol. 27, no. 158 , p. 1 .
} 
of the space, with clear geographical boundaries and the presence of a landfill, played a significant role. The environmental issues connected with the proximity of the landfill was at the root of the ghetto's development. Once the space became inhabited predominantly by Roma, it became a place (in the eyes of the majority, and/or decision-makers) unsuitable for the kind of investments seen in other parts of the city. As the results of the qualitative survey indicate, the area inhabited by the Roma in Luník IX started to be viewed by the majority as 'lost ground' or territory beyond the pale.

The city archives provide evidence that from the beginning of its construction the district was stigmatised by the close presence of the landfill and the heavy traffic to and from the landfill, and that the public authorities were clearly aware of the problem. Luník IX is today a phenomenon that could provide important data, information, and inputs for environmental justice research. The empirical evidence from this case contributes to current theoretical and empirical knowledge in the field of environmental justice, while it provides additional arguments for the study of the economic and policy landscape of decision-making at the local level. Qualitative research combined with an analysis of historical records helps to reveal how public discourse differs from historical facts and how ethnic and/or social prejudices may shape explanatory frameworks.

The location of the ethnic Roma minority and the evolution of the space that the Roma minority live in this district and the way the space has evolved are not simply the result of an individual decision or the individual economic options that make it (or do not make it) possible to choose a place in which to live. They are also the result of the opposite movement. There is a great deal of vested interest in putting environmentally problematic projects in poor neighbourhoods or, conversely, as indicated in the case of Luník IX, in moving poor and/or ethnically stigmatised people into an area where such a project is already located.

Research on the roots and processes of ghettoisation combined with an environmental justice perspective may provide important arguments for public policy and practice. The Roma community in Luník IX is quite disparate and very heterogeneous, consisting of people who were originally offered accommodation here and people who were evicted later on from different parts of the city. A qualitative survey indicates that there is an increasing trend towards collective action and that people living in the area are starting to organise. There are Roma political parties active here and Roma mayors elected in direct elections. Although the self-organisation and self-governance is to a great extent the outcome of the segregation, it indicates the population's increasing awareness. Using the environmental justice perspective, with its focus on distributive and procedural justice, may provide important arguments for shifting the public discourse away from comfortable myths about green urban space to evidence-based discussion and decisions. 
RICHARD FILČÁK is a senior researcher at the Institute for Forecasting, Centre of Social and Psychological Sciences of the Slovak Academy of Sciences. His work and research interests are focused on environmental and social policy development and trends in the transition countries of Central and Eastern Europe, with particular attention devoted to environmental justice, EU economic and social cohesion policies, industrial development, and climate change.

ONDREJ FicERI is a researcher at the Institute of Social Sciences, Centre of Social and Psychological Sciences of the Slovak Academy of Sciences. His research focuses on social and urban history and ethnic studies. His recent publications include the article 'The Traitorous National Periphery: the Legacy of Identity Politics of Imperial Hungary in a New Eastern Metropolis of Czechoslovakia - Košice/Kassa' published in the European Review of History: Revue européenne d'histoire.

\section{References}

Bullard, R. D. 1990. Dumping in Dixie: Race, Class, and Environmental Quality. Boulder, CO: Westview Press.

Bullard, R. D. 1993. 'Race and Environmental Justice in the United States.' Yale Journal of International Law 18 (1): 319-335. Retrieved 1 November 2020 (http://digitalcommons.law.yale.edu/yjil/vol18/iss1/12).

Commission for Racial Justice (CfRJ). 1987. Toxic Wastes in the United States: A National Report on the Racial and Socio-Economic Characteristics of Communities with Hazardous Waste Sites. United Church of Christ Commission for Racial Justice. Retrieved 1 November 2020 (https://www.nrc.gov/docs/ML1310/ML13109A339.pdf).

Blaive, M. (ed.) 2018. Perceptions of Society in Communist Europe: Regime Archives and Popular Opinion. London and New York: Bloomsbury Academic.

Davis, M. 2004. 'Planet of Slums: Urban Involution and the Informal Proletariat.' New Left Review (26): 5-34.

Dohotaru, A.O. 2013. 'Performative Anthropology. The Case of the Pata-Rât Ghetto.' Studia Ubb Sociologia 58: 193-217.

Douglas, M. 1966. Purity and Danger: An Analysis of Concepts of Pollution and Taboo. New York: Routledge.

Filčák, R. 2012. Living Beyond the Pale: Environmental Justice and the Roma Minority. Budapest and New York: CEU Press.

Filčák, R. and T. Steger. 2014. 'Ghettos in Slovakia. Confronting Roma Social and Environmental Exclusion.' Analyse E Kritik: Zeitschrift für Sozialtheorie 36 (2): 229-250.

Gajdoš, P. and M. Moravanská. 2016. Sídelný vývoj na Slobensku (1990-2014) a jeho sociálno-priestorové kontexty a dopady. (Settlement history in Slovakia (1990-2014) and its socio-spatial contexts and consequences) Bratislava: Sociologický ústav SAV.

Holifield, R., J. Chakraborty and G. Walker. 2017. The Routledge Handbook of Environmental Justice. London: Routledge, https://doi.org/10.4324/9781315678986.

Jurová, A. 1993. Vývoj rómskej problematiky na Slovensku po roku 1945. (The development of the Roma question in Slovakia after 1945) Bratislava: Golders Publishers. 
Jurová, A. 2015. 'Likvidácia Tábora a vznik sídliska Luník IX.' (The destruction of Tábor and the inception of Luník IX) Mesto a dejiny 4 (1): 30-49.

Keucheyan, R. 2016. Nature Is a Battlefield: Towards a Political Ecology. Cambridge: Polity Press.

Kornai, J. 1980. Economics of Shortage: Contributions to Economic Analysis. Elsevier Science.

Kornai, J. 1988. The Socialist System: The Political Economy of Communism. Princeton, NJ: Princeton University Press.

Ladanyi, J. and I. Szelenyi. 1998. 'Class, Ethnicity and Urban Restructuring in Postcommunist Hungary.' Pp. 109-136 in Social Change and Urban Restructuring in Central Europe, edited by G. Enyedi. Budapest: Akademiai Kiado.

Ledeneva, A. 1998. Russia Economies of Favour: Blat, Networking and Informal Exchange. Cambridge: Cambridge University Press.

Lipton, D. and J. Sachs. 1990. ‘Creating a Market Economy in Eastern Europe: The Case of Poland.' Brookings Papers on Economic Activity. Retrieved 1 November 2020 (https://core.ac.uk/download/pdf/6340549.pdf), https://doi.org/10.2307/2534526.

Logan, J. R. and H. Molotch. 1987. Urban Fortunes: The Political Economy of Place. Berkley, CA: University of California Press.

Matoušek, R. and L. Sýkora. 2011. 'Environmental Justice and Residential Segregation in Czechia: the Case of Roma Resettlement in the Town of Vsetín.' AUC Geographica (46): 81-94, https://doi.org/10.14712/23361980.2015.33.

Mesto Košice. 2013. Koncepcia komplexného riešenia situácie na sídlisku Luník IX: Komunitný a strategický plán Košice - Luník IX. (The conception for complex solution of the situation at the housing estate of Luník IX: the community and strategic plan for Košice - Luník IX). Košice: Mesto Košice.

McGarry, A. 2017. Romaphopia: the Last Acceptable Form of Racism. London: Zed Books, https://doi.org/10.5040/9781350222434.

McGurty, E.M. 2000. 'Warren County, NC, and the Emergence of the Environmental Justice Movement: Unlikely Coalitions and Shared Meanings in Local Collective Actions.' Society and Natural Resources 13: 373-387, https://doi.org/10.1080/089419200279027.

Millar, K.M. 2018. Reclaiming the Discarded: Life and Labor on Rio's Garbage Dump. Durham, NC: Duke University Press, https://doi.org/10.1215/9780822372073.

Molotch, H. 1976. 'The City as a Growth Machine: Toward a Political Economy of Place.' American Journal of Sociology 82 (2): 309-332, https:// doi.org/10.1086/226311.

Pellow, D. 2002. Garbage Wars: The Struggle for Environmental Justice in Chicago. Cambridge, MA: MIT Press, https://doi.org/10.7551/mitpress/3195.001.0001.

Picker, G. 2017. Racial Cities: Governance and the Segregation Of Romani People in Urban Europe. London and New York: Routledge, https://doi.org/10.4324/9781315750460.

Polanyi, K. 1944. The Great Transformation: The Political and Economic Origins of Our Time. Boston, MA: Beacon Press.

Pulido, L. 2010. 'Rethinking Environmental Racism: White Privilege and Urban Development in Southern California.' Annals of the Association of American Geographers 90 (1): 12-40, https:// doi.org/10.1111/0004-5608.00182.

Pullmann, M. 2011. Konec experimentu: přstavba a pád komunismu v Československu. (The end of an experiment: remodelling and the fall of communism in Czechoslovakia) Prague: Scriptorium.

Rhodes, E. L. 2003. Environmental Justice in America: A New Paradigm. Bloomington, ID: Indiana University Press.

Sosna, D. 2016. 'Heterotopias behind the Fence: Landfills as Relational Emplacement.' Pp. 162-179 in Archaeologies of Waste: Encounters with the Unwanted, edited by D. Sosna and L. Brunclíková. Oxford: Oxbow Books. 
Schlosberg, D. 1999. Environmental Justice and the New Pluralism: The Challenge of Difference for Environmentalism. Oxford: Oxford University Press.

Schlosberg, D. 2002. Moral and Political Reasoning in Environmental Practice. Cambridge, MA: MIT Press.

Schlosberg, D. 2007. Defining Environmental Justice: Theories, Movements, and Nature. Oxford: Oxford University Press, https://doi.org/10.1093/acprof:oso/9780199286294.001.0001.

Spurný, M. 2012. Nejsou jako my: česká společnost a menšiny v pohraničí 1945-1960.

(They are not like us: Czech society and minorities in the borderlands 1945-1960) Prague: Antikomplex.

Spurný, M. 2016. Most do budoucnosti: laboratoř socialistické modernity na severu Čech (Most in the future: a laboratory of socialist modernity in northern Bohemia) Prague: Karolinum.

Steger, T., A. Antypas, L. Atkins, F. Borthwick, C. Cahn, R. Filčák, K. Harper, I. Malbasic and K. Medarova. 2007. Making the Case for Environmental Justice in Central and Eastern Europe. Budapest: Central European University/Centre for Environmental Policy and Law.

Uhrínová, S. 2013. 'Uzatvorenie a rekultivácia skládky odpadov Myslava.' (The closure and re-cultivation of the Myslava landfill) Košice: Mesto Košice. August 13. Retrieved March 10, 2019 (http://www.daff.gov.au/_data/assets/pdf_file/0014/152105/aaws_ stocktake_livestock_prod.pdf).

Velicua, I. and M. Kaikab. 2015. 'Undoing Environmental Justice: Re-imagining Equality in the Rosia Montana Anti-mining Movement.' Geoforum 84: 305-315, https://doi.org/10.1016/j.geoforum.2015.10.012.

Vincze, E. and C. Raț. 2013. 'Spatialization and Racialization of Social Exclusion. The Social and Cultural Formation of "Gypsy Ghettos" in Romania in a European Context.' Studia Ubb Sociologia 58: 5-21.

Wacquant, L. 2004. 'Ghetto.' Pp. 1-7 in International Encyclopedia of the Social and Behavioral Sciences, edited by N. J. Smelser and P. B. Baltes. London: Harper, https://doi.org/10.1016/B0-08-043076-7/99103-4.

Wacquant, L. 2012. 'A Janus-Faced Institution of Ethnoracial Closure: A Sociological Specification of the Ghetto.' Pp. 1-32 in The Ghetto. Contemporary Global Issues and Controversies, edited by R. Hutchison and B. D. Haynes. Boulder, CO: Westview Press, https://doi.org/10.4324/9780429496516-1.

Walker, G., J. Fairburn, G. Smith and G. Mitchell. 2003. Environmental Quality and Social Deprivation. Bristol: Environment Agency. 